\title{
Propofol-remifentanil is More Effective than Propofol- fentanyl in Decreasing Intraoperative Blood Loss during Sagittal Split Ramus Osteotomy
}

\author{
Toshiyuki Handa ${ }^{1)}$, Takaaki Onodera ${ }^{2)}$, Yoshifumi Honda ${ }^{3)}$, \\ Yoshihiko Koukita $^{1)}$ and Tatsuya Ichinohe ${ }^{1)}$ \\ ${ }^{1)}$ Department of Dental Anesthesiology, Tokyo Dental College, \\ 2-9-18 Misaki-cho, Chiyoda-ku, Tokyo 101-0061, Japan \\ 2) Ikeda Dental Clinic, \\ 3-8-3 Igodai, Narita-shi, Chiba 286-0035, Japan \\ ${ }^{3)}$ National Hospital Organization Takasaki General Medical Center, \\ 36 Takamatsumachi, Takasaki-shi, Gunma 370-0829, Japan
}

Received 10 February, 2016/Accepted for publication 17 March, 2016

\begin{abstract}
This study retrospectively compared blood loss during sagittal split ramus osteotomy in patients receiving propofol-remifentanil ( $\mathrm{R}$ group) and those receiving propofol-fentanyl (F group). All patients underwent sagittal split ramus osteotomy under general anesthesia during the 3-year 4-month period between October 2007 and February 2011 in an operating room at Tokyo Dental College Suidobashi Hospital. Blood loss in the R group was significantly less than that in the $\mathrm{F}$ group. Mean arterial pressure and heart rate, measured at 20 and $15 \mathrm{~min}$ after tracheal intubation, respectively, were both lower in the R group. No marked change was observed in blood pressure in the R group under general anesthesia, however. Volume of urine was also larger in the $\mathrm{R}$ group. The results of this study suggest that remifentanil is effective in reducing intraoperative blood loss during sagittal split ramus osteotomy.
\end{abstract}

Key words: Propofol—Remifentanil—Sagittal split ramus osteotomy — Blood loss

\section{Introduction}

Clinically, this group has found that surgery for jaw deformities involves less blood loss when performed under anesthesia with propofol-remifentanil than with propofol-fentanyl. In addition, studies using Japan White rabbits have shown that continuous infusion of remifentanil significantly decreased tissue blood flow in mandibular bone marrow ${ }^{3,4)}$.

The purpose of the present study was to retrospectively compare the effects of various narcotic analgesics used in conjunction with propofol on intraoperative blood loss and hemodynamic variables to clinically verify findings reported in rabbit model studies. 


\section{Patients and Methods}

This study was conducted with the approval of the Ethics Committee of Tokyo Dental College (Approval number: 399). All the patients included underwent sagittal split ramus osteotomy under general anesthesia during the 3-year 4-month period between October 2007 and February 2011 in an operating room at Tokyo Dental College Suidobashi Hospital. Patients with an American Society of Anesthesiologists Physical Status (PS) score of 2 or higher and those taking oral psychotropic agents or anticoagulants were excluded. Patients in whom nitrous oxide or an inhaled anesthetic was used were also excluded. Thus, only patients in whom fentanyl (F group) or remifentanil ( $\mathrm{R}$ group) were concomitantly used under air-oxygen and propofol anesthesia were extracted for the analysis.

Patient characteristics obtained from anesthesia records included age, sex, height, weight, duration of surgery, duration of anesthesia, total fluid infusion, total dose of fentanyl in the F group, total dose of remifentanil in the $\mathrm{R}$ group, blood loss during surgery, urine output, and intraoperative mean blood pressure and heart rate. Mean arterial pressure was calculated as diastolic blood pressure plus one third of pulse pressure at each observation point in the anesthesia records. To compare intraoperative hemodynamic variables between the two groups, differences in mean arterial pressure and heart rate were monitored for $120 \mathrm{~min}$ after tracheal intubation. In the statistical analysis, the Student $t$-test was used for unpaired samples and the Mann-Whitney U test where appropriate. A p-value of less than $5 \%$ indicated a significant difference.

\section{Results}

A total of 262 patients underwent sagittal split ramus osteotomy under general anesthesia during the study period. Excluded patients included the following: 1 patient with a PS score of higher than 2; 4 patients who were
Table 1 Patient characteristics

\begin{tabular}{lcc}
\hline \hline & F group & R group \\
\hline Age $(\mathrm{yr})$ & $26.9 \pm 8.1$ & $25.8 \pm 8.4$ \\
Sex $(\mathrm{M} / \mathrm{F})$ & $20 / 45$ & $19 / 47$ \\
Height $(\mathrm{cm})$ & $164.1 \pm 9.0$ & $163.4 \pm 8.2$ \\
Weight $(\mathrm{kg})$ & $55.9 \pm 10.7$ & $57.1 \pm 9.0$ \\
\hline
\end{tabular}

taking oral psychotropic agents; and 126 patients given nitrous oxide or an inhaled anesthetic. As a result, a total of 131 patients were included in the analysis, comprising 65 in the F group and 66 in the R group.

All patients underwent target-controlled infusion at a predicted blood propofol concentration of $3.5 \mu \mathrm{g} / \mathrm{ml}$ during the induction of anesthesia. A bolus intravenous injection of $100 \mu \mathrm{g}$ fentanyl was given in the $\mathrm{F}$ group before administration of propofol, whereas the $\mathrm{R}$ group was given continuous infusion of remifentanil at $0.25 \mu \mathrm{g} / \mathrm{kg} / \mathrm{min}$. Anesthesia was maintained at a predicted blood propofol concentration of $3.0-4.0 \mu \mathrm{g} / \mathrm{ml}$, with bolus injections of $1-2 \mu \mathrm{g} / \mathrm{kg}$ fentanyl in the F group or continuous infusion of remifentanil at $0.25-$ $0.4 \mu \mathrm{g} / \mathrm{kg} / \mathrm{min}$ in the $\mathrm{R}$ group. Rocuronium was administered at a bolus dose of $0.6 \mathrm{mg} / \mathrm{kg}$ for tracheal intubation, and then by continuous intravenous injections at $7 \mu \mathrm{g} / \mathrm{kg} / \mathrm{min}$ in all patients. A total of $16 \mathrm{ml}$ of $2 \%$ lidocaine hydrochloride with $12.5 \mu \mathrm{g} / \mathrm{ml}$ epinephrine was administered to the surgical field in all patients together with a 50-mg diclofenac sodium suppository on completion of the surgical procedure. In addition, the $\mathrm{R}$ group received a bolus injection of fentanyl at $2.0 \mu \mathrm{g} / \mathrm{kg}$ approximately $20 \mathrm{~min}$ before the end of the surgical procedure.

No significant differences in patient backgrounds were observed between the two groups (Table 1). Moreover, no differences were revealed in duration of surgery, duration of anesthesia, or total volume of fluid infusion between the two groups. Patients in the F group received a total dose of fentanyl of $443.8 \pm 92.4 \mu \mathrm{g}$, and those in the $\mathrm{R}$ group a 
Table 2 Intraoperative data

\begin{tabular}{lccc}
\hline \hline & F group & R group & p-value \\
\hline Duration of surgery $(\mathrm{min})$ & $112.0 \pm 29.5$ & $115.8 \pm 16.4$ & $\mathrm{p}=0.183$ \\
Duration of anesthesia $(\mathrm{min})$ & $179.4 \pm 27.8$ & $183.4 \pm 20.3$ & $\mathrm{p}=0.177$ \\
Total volume of fluid infusion $(\mathrm{ml})$ & $1,968.5 \pm 502.1$ & $1,830.8 \pm 326.8$ & $\mathrm{p}=0.164$ \\
Total dose of fentanyl $(\mu \mathrm{g})$ & $443.8 \pm 92.4$ & - & \\
Total dose of remifentanil $(\mu \mathrm{g})$ & - & $2,350.0 \pm 631.5$ & \\
Volume of urine output $(\mathrm{ml})$ & $420.8 \pm 293.0$ & $567.5 \pm 295.0$ & $\mathrm{p}=0.005$ \\
Amount of blood loss $(\mathrm{ml})$ & $171.7 \pm 130.2$ & $118.4 \pm 69.6$ & $\mathrm{p}=0.004$ \\
\hline
\end{tabular}

Table 3 Intraoperative mean arterial pressure and heart rate

\begin{tabular}{|c|c|c|c|c|c|c|c|c|c|c|c|c|c|c|c|c|}
\hline & & Control & $\begin{array}{c}5 \\
\min \end{array}$ & $\begin{array}{c}10 \\
\min \end{array}$ & $\begin{array}{c}15 \\
\min \end{array}$ & $\begin{array}{l}20 \\
\min \end{array}$ & $\begin{array}{c}30 \\
\text { min }\end{array}$ & $\begin{array}{c}40 \\
\min \end{array}$ & $\begin{array}{c}50 \\
\text { min }\end{array}$ & $\begin{array}{c}60 \\
\min \end{array}$ & $\begin{array}{c}70 \\
\min \end{array}$ & $\begin{array}{c}80 \\
\min \end{array}$ & $\begin{array}{c}90 \\
\text { min }\end{array}$ & $\begin{array}{l}100 \\
\min \end{array}$ & $\begin{array}{l}110 \\
\text { min }\end{array}$ & $\begin{array}{l}120 \\
\text { min }\end{array}$ \\
\hline \multirow{3}{*}{$\begin{array}{c}\text { MAP } \\
(\mathrm{mmHg})\end{array}$} & $\mathrm{F}$ group & $\begin{array}{c}86.6 \\
\pm \\
9.2\end{array}$ & $\begin{array}{c}80.4 \\
\pm \\
9.7\end{array}$ & $\begin{array}{c}80.3 \\
\pm \\
14.8\end{array}$ & $\begin{array}{c}78.4 \\
\pm \\
13.0\end{array}$ & $\begin{array}{c}77.5 \\
\pm \\
10.6\end{array}$ & $\begin{array}{c}78.9 \\
\pm \\
10.0\end{array}$ & $\begin{array}{c}77.4 \\
\pm \\
12.1\end{array}$ & $\begin{array}{c}77.0 \\
\pm \\
11.0\end{array}$ & $\begin{array}{c}80.2 \\
\pm \\
12.3\end{array}$ & $\begin{array}{c}81.5 \\
\pm \\
10.2\end{array}$ & $\begin{array}{c}83.6 \\
\pm \\
14.5\end{array}$ & $\begin{array}{c}86.6 \\
\pm \\
14.7\end{array}$ & $\begin{array}{c}85.5 \\
\pm \\
14.5\end{array}$ & $\begin{array}{c}84.4 \\
\pm \\
14.0\end{array}$ & $\begin{array}{c}84.0 \\
\pm \\
13.1\end{array}$ \\
\hline & & $\begin{array}{c}88.4 \\
\pm \\
10.0\end{array}$ & $\begin{array}{c}80.4 \\
\pm \\
13.6\end{array}$ & $\begin{array}{c}78.2 \\
\pm \\
11.9\end{array}$ & $\begin{array}{c}75.7 \\
\pm \\
8.8\end{array}$ & $\begin{array}{c}71.9 \\
\pm \\
8.3\end{array}$ & $\begin{array}{c}72.5 \\
\pm \\
7.5\end{array}$ & $\begin{array}{c}70.7 \\
\pm \\
9.0\end{array}$ & $\begin{array}{c}71.3 \\
\pm \\
10.5\end{array}$ & $\begin{array}{c}68.6 \\
\pm \\
8.3\end{array}$ & $\begin{array}{c}71.4 \\
\pm \\
9.1\end{array}$ & $\begin{array}{l}69.2 \\
\pm \\
8.7\end{array}$ & $\begin{array}{c}66.9 \\
\pm \\
7.5\end{array}$ & $\begin{array}{c}69.3 \\
\pm \\
7.3\end{array}$ & $\begin{array}{c}67.6 \\
\pm \\
7.0\end{array}$ & $\begin{array}{c}68.3 \\
\pm \\
7.5\end{array}$ \\
\hline & $\mathrm{R}$ vs $\mathrm{F}$ & & & & & $*$ & $*$ & $*$ & $*$ & $*$ & $*$ & $*$ & $*$ & $*$ & $*$ & $*$ \\
\hline \multirow{3}{*}{$\begin{array}{c}\text { HR } \\
\text { (bpm) }\end{array}$} & $\mathrm{F}$ group & $\begin{array}{c}66.8 \\
\pm \\
11.0\end{array}$ & $\begin{array}{c}62.9 \\
\pm \\
11.7\end{array}$ & $\begin{array}{l}63.0 \\
\pm \\
11.8\end{array}$ & $\begin{array}{c}65.0 \\
\pm \\
10.8\end{array}$ & $\begin{array}{c}64.7 \\
\pm \\
11.3\end{array}$ & $\begin{array}{c}65.3 \\
\pm \\
11.1\end{array}$ & $\begin{array}{c}73.0 \\
\pm \\
13.7\end{array}$ & $\begin{array}{c}74.4 \\
\pm \\
11.0\end{array}$ & $\begin{array}{c}76.6 \\
\pm \\
12.0\end{array}$ & $\begin{array}{c}79.3 \\
\pm \\
13.0\end{array}$ & $\begin{array}{c}79.6 \\
\pm \\
11.3\end{array}$ & $\begin{array}{c}78.4 \\
\pm \\
11.5\end{array}$ & $\begin{array}{c}74.2 \\
\pm \\
11.9\end{array}$ & $\begin{array}{c}72.1 \\
\pm \\
11.5\end{array}$ & $\begin{array}{c}70.2 \\
\pm \\
11.2\end{array}$ \\
\hline & $\mathrm{R}$ group & $\begin{array}{c}70.3 \\
\pm \\
11.7\end{array}$ & $\begin{array}{c}62.0 \\
\pm \\
10.7\end{array}$ & $\begin{array}{c}60.8 \\
\pm \\
9.2\end{array}$ & $\begin{array}{c}60.0 \\
\pm \\
9.0\end{array}$ & $\begin{array}{c}59.5 \\
\pm \\
9.0\end{array}$ & $\begin{array}{c}59.5 \\
\pm \\
9.1\end{array}$ & $\begin{array}{c}64.9 \\
\pm \\
10.1\end{array}$ & $\begin{array}{c}66.5 \\
\pm \\
9.0\end{array}$ & $\begin{array}{c}66.5 \\
\pm \\
10.6\end{array}$ & $\begin{array}{c}67.6 \\
\pm \\
7.2\end{array}$ & $\begin{array}{c}67.2 \\
\pm \\
7.7\end{array}$ & $\begin{array}{c}64.5 \\
\pm \\
7.7\end{array}$ & $\begin{array}{c}62.4 \\
\pm \\
8.0\end{array}$ & $\begin{array}{c}60.9 \\
\pm \\
6.8\end{array}$ & $\begin{array}{c}59.6 \\
\pm \\
7.0\end{array}$ \\
\hline & $\mathrm{R}$ vs $\mathrm{F}$ & & & & $*$ & $*$ & $*$ & $*$ & $*$ & $*$ & $*$ & $*$ & $*$ & $*$ & $*$ & $*$ \\
\hline
\end{tabular}

$*: \mathrm{p}<0.05$ between two groups

MAP: mean arterial pressure, HR: heart rate, F: fentanyl, R: remifentanil, min: minutes

total dose of remifentanil of 2,350.0 \pm 631.5 $\mu \mathrm{g}$ (Table 2).

Mean blood loss in the $\mathrm{R}$ group was $118.4 \pm 69.6 \mathrm{ml}$, which was smaller than that in the $\mathrm{F}$ group $(171.7 \pm 130.2 \mathrm{ml})$ (Table 2). Mean arterial pressure and heart rate, measured at 20 and 15 min after tracheal intubation, respectively, were lower in the $\mathrm{R}$ group (Table 3). A significant difference was also seen in the mean volume of urine output between the two groups $(567.5 \pm 295.0 \mathrm{ml}$ in the $\mathrm{R}$ group vs. $420.8 \pm 293.0 \mathrm{ml}$ in the $\mathrm{F}$ group; Table 2).

\section{Discussion}

The results of this study revealed that blood loss was lower with administration of remifentanil than with fentanyl during sagittal split ramus osteotomy.

It has been reported that blood loss during jaw deformity surgery showed a positive correlation with duration of surgery ${ }^{7}$. In the present study, duration of surgery was similar between the two groups, and was therefore unlikely to have influenced the volume of blood loss observed.

Induced hypotension has been used to 
decrease blood loss in highly invasive surgeries of the jaw bone such as sagittal split ramus osteotomy. In a previous study, it was reported that induced hypotension during jaw deformity surgery was effective in avoiding blood transfusion when the mean blood pressure was maintained at $50-60 \mathrm{mmHg}^{6)}$. The results of the present study showed that the mean blood pressure was maintained at around $80 \mathrm{mmHg}$ in the $\mathrm{F}$ group and $70 \mathrm{mmHg}$ in the $\mathrm{R}$ group. Thus, while intraoperative blood pressure decreased to some extent in both groups, it did reach levels as low as those achieved with induced hypotension.

Remifentanil can cause bradycardia and reduce blood pressure due to parasympathetic activation and sympatholytic effects ${ }^{1)}$. A study in patients undergoing tympanoplasty compared the effects of induced hypotension under air-oxygen and propofol anesthesia with $0.25-0.5 \mu \mathrm{g} / \mathrm{kg} / \mathrm{min}$ remifentanil, $0.25 \mu \mathrm{g} /$ $\mathrm{kg} / \mathrm{min}$ sodium nitroprusside (SNP), or $100-300 \mu \mathrm{g} / \mathrm{kg} / \mathrm{min}$ esmolol hydrochloride (ESMO) by measuring middle ear blood flow. Remifentanil or SNP elicited a greater decrease in middle ear blood flow than $\mathrm{ESMO}^{2}$. However, SNP decreased $\mathrm{pH}$ and increased $\mathrm{PaCO}_{2}$. Based on these results, the authors concluded that remifentanil reduced tissue blood flow in the middle ear and provided good surgical conditions for tympanoplasty. Another study using Japan White rabbits reported that remifentanil reduced mandibular bone marrow blood flow when infused at a clinical dose of $0.25 \mu \mathrm{g} / \mathrm{kg} / \mathrm{min}$ during $12 \mathrm{mg} / \mathrm{kg} / \mathrm{hr}$ propofol anesthesia, although almost no change was observed in carotid artery blood flow ${ }^{3}$. In the present study, remifentanil reduced blood pressure and decreased blood loss. However, as this was a retrospective study, it was not possible to investigate whether there was any correlation between this observed reduction in blood loss and decrease in blood pressure. This indicates the need for further prospective study to clarify whether the observed reduction in blood loss with administration of remifentanil is due to hypotension or a reduction in tissue blood flow.
The volume of urine was greater in the $\mathrm{R}$ group. This result is consistent with that of Myles $e t a l^{5}$. It has been suggested that this increase in the volume of urine with administration of remifentanil is due to subsequent inhibition of excretion of catecholamine and cortisol, although this remains to be confirmed ${ }^{5,8}$. This increase in urine and concomitant decrease in blood pressure suggests that adequate renal blood flow was ensured during mild hypotension.

In conclusion, the results of this study revealed that continuous infusion of remifentanil during sagittal split ramus osteotomy reduced blood loss without any excessive decrease in blood pressure.

\section{References}

1) Beers R, Camporesl E (2004) Remifentanil update: clinical science and utility. CNS Drugs 18:1085-1104.

2) Degoute CS, Ray MJ, Manchon M, Dubreuil C, Banssillon V (2001) Remifentanil and controlled hypotension comparison with nitroprusside or esmolol during tympanoplasty. Can J Anesth 48:20-27.

3) Kemmochi M, Ichinohe T, Kaneko Y (2009) Remifentanil decreases mandibular bone marrow blood flow during propofol or sevoflurane anesthesia in rabbits. J Oral Maxillofac Surg 67:1245-1250.

4) Koshika K, Ichinohe T, Kaneko Y (2011) Dosedependent remifentanil decreases oral tissue blood flow during sevoflurane and propofol anesthesia in rabbits. J Oral Maxillofac Surg 69:2128-2134.

5) Myles PS, HuntJO, Fletcher H, Watts J, Bain D, Silvers A, Buckland MR (2002) Remifentanil, fentanyl, and cardiac surgery: a doubleblinded, randomized controlled trial of coats and outcomes. Anesth Analg 95:805-812.

6) Ueki K, Marukawa K, Shimada M, Nakagawa K, Yamamoto E (2005) The assessment of blood loss in orthognathic surgery for prognathia. J Oral Maxillofac Surg 63:350-354.

7) Varol A, Basa S, Ozturk S (2010) The role of controlled hypotension upon transfusion requirement during maxillary downfracture in double-jaw surgery. J Craniomaxillofac Surg 38:345-349.

8) Winterhalter M, Brandl K, Rahe-Meyar N, 
Osthaus A, Hecker H, Hagl C, Adams HA, Piepenbrock S (2008) Endocrine stress response and inflammatory activation during CABG surgery: a randomized trial comparing remifentanil infusion to intermittent fentanyl. Eur J Anesthesiol 25:326-335.
Correspondence:

Dr. Toshiyuki Handa

Department of Dental Anesthesiology,

Tokyo Dental College,

2-9-18 Misaki-cho, Chiyoda-ku,

Tokyo 101-0061, Japan

E-mail: handa@tdc.ac.jp 